• 研究报告・

\title{
中国极小种群野生植物的保护现状评估
}

\author{
张则瑾 1,2 郭炎培 ${ }^{2}$ 贺金生 $^{2} \quad$ 唐志尧 $^{2 *}$ \\ 1 (中国科协创新战略研究院, 北京 100863) \\ 2 (北京大学城市与环境学院, 北京 100871)
}

\begin{abstract}
摘要: 广阔的地域和多样的地形造就了中国丰富的生物多样性, 同时长时间的人类活动也导致我国有不少物种的 生存受到威胁, 特别是一些极度濒危、随时有灭绝危险、生境要求独特、生态幅狭窄或基因易流失的物种需要重 点保护。近期国家出台了《全国野生动植物及自然保护区建设工程总体规划》, 其中包含了首批重点保护的极小 种群植物名单。本研究中, 我们整理了120种极小种群野生植物的高精度分布图, 探讨其分布格局并通过国家级和 省级保护区网络评估其保护现状。研究发现, 中国极小种群野生植物丰富度最高的地方是云南东南部、广西西南 部和海南岛西南部。国家级自然保护区对中国极小种群野生植物分布区的平均覆盖率为21.5\%, 省级自然保护区 的平均覆盖率为 $10.9 \%$ 。有35种极小种群野生植物(占总数的 $29 \%$ )未受国家级自然保护区覆盖, 有 17 种(14\%)未受 任何国家级或省级自然保护区覆盖。我们建议在云南和海南省针对极小种群建立自然保护区。
\end{abstract}

关键词: 自然保护区; 格局; 物种丰富度; 极小种群野生植物

\section{Conservation status of Wild Plant Species with Extremely Small Popula- tions in China}

Zejin Zhang ${ }^{1,2}$, Yanpei Guo ${ }^{2}$, Jin-Sheng $\mathrm{He}^{2}$, Zhiyao Tang ${ }^{2 *}$

1 National Academy of Innovation Strategy, Beijing 100863

2 College of Urban and Environmental Sciences, Peking University, Beijing 100871

\begin{abstract}
China is characterized as one of the countries with the greatest diversity worldwide, mostly because of its vast area and heterogeneous topography. Meanwhile, the long history of human activity has led to the decrease of populations for considerable species in China. To protect these species, the Chinese government proposed a list of the first batch of Wild Plant Species with Extremely Small Populations (PSESP). In this study, we developed a fine-resolution distribution database for 120 PSESPs, explored the distribution patterns, and evaluated the in situ conservation status of the PSESPs by overlapping species distribution with terrestrial national and provincial nature reserves (NNRs and PNRs) in China. We found the greatest richness of PSESPs in the southeast regions of Yunnan, the southwest regions of Guangxi, and the southwest regions of Hainan Island. On average, NNRs covered 21.5\%, while PNRs covered an additional 10.9\% of the distribution areas of PSESPs. However, 35 PSESPs (29\% of the total) were not covered by NNRs and 17 PSESPs (14\%) were not covered by either NNRs or PNRs. We proposed that nature reserves specifically designed for the PSESPs need to be constructed in the Yunnan and Hainan provinces.
\end{abstract}

Key words: nature reserves; pattern; species richness; PSESP

生物多样性是全球生态系统正常运转和人类 生存的基础(Rands et al, 2010; Brugiere \& Scholte, 2013)。由于土地利用/土地覆盖变化、资源的过度 利用、全球气候变化和环境污染等因素, 生物多样
性正受到严重破坏, 生物多样性的灭绝速度已经远 超过其自然灭绝速度(Balmford et al, 2003; Millennium Ecosystem Assessment, 2005; Monastersky, 2014; Teller et al, 2015)。为了保护地球生物多样性,

收稿日期: 2017-10-28; 接受日期: 2018-01-04

基金项目: 国家自然科学基金(31170499, 31021001)和环保公益性行业科研专项(201209028)

* 通讯作者 Author for correspondence. E-mail: zytang@urban.pku.edu.cn 
全球自然保护区网络在世界各国的共同努力下日 趋完善(Rabb \& Sullivan, 1995; Rodrigues et al, 2004; Kullberg \& Moilanen, 2014)。然而就中国而言, 目前 我国的保护区网络依然存在保护空白, 还需要逐步 努力来优化改进(Grenyer et al, 2006; 唐小平, 2012; Wu et al, 2013; Zhang et al, 2015a, b)。

野生植物是生态系统的重要组成, 研究表明, 一种植物一般与 10-30种其他生物共存, 也就是说, 一种植物灭绝会影响其他10-30种生物的生存(廖菊 阳等, 2015)。根据1997-2003年对全国重点保护野生 植物资源的调查, 百山祖冷杉 (Abies beshanzuensis)、银杉(Cathaya argyrophylla)、华盖木(Pachylarnax sinica)等55种野生植物的野外种群大小低于 稳定存活界限, 随时面临着野外灭绝的危险; 银缕 梅(Parrotia subaequalis)和宝华玉兰(Yulania zenii) 等国家重点保护物种, 以及其他经济、文化价值较 高的物种也遭受着丧失的风险(中华人民共和国林 业局, 2011)。国家林业局由此提出极小种群野生植 物(Wild Plant Species with Extremely Small Populations, PSESP)的概念，特指分布地域狭窄或呈间断 分布、长期受到外界因素胁迫干扰而呈现出种群退 化和数量持续减少、种群及个体数量都极少, 已经 低于稳定存活界限的最小可存活种群而随时濒临 灭绝的野生植物种类(Ren et al, 2012)。一方面, 这 些极小种群植物多为我国特有, 具有重要的生态和 经济价值; 另一方面, 由于野生植物生存能力下降, 人为活动引起的生境破坏以及资源过度利用导致 极小种群更容易濒危(Ren et al, 2012)。鉴于极小种 群野生植物是最易丧失的生物资源之一, 对其进行 保护是生物多样性保护的重中之重。如果保护不够 及时, 极小种群物种的生物特征和基因价值可能在 人类尚未了解之前就伴随着物种的灭绝而消失了, 最终将给生态系统和人类社会带来不可估量的损 失。因此, 保护极小种群有助于延缓物种灭绝, 维 护生态平衡, 保存资源, 促进生态可持续发展, 对 于我国的生物多样性保护具有极为重要的意义。

由于极小种群对生境的特殊要求, 因此维护现 存自然生境是保护极小种群野生植物的重要方式 之一(周云等, 2012)。为了落实对极小种群的保护工 作, 依据受威胁程度及其经济、科研、文化等因素 (Yang \& Yang, 2014), 《全国野生动植物及自然保护 区建设工程总体规划》最终确定了首批重点保护的
120种极小种群野生植物, 其中含国家I级保护植物 36种, 国家II级保护植物26种, 省级重点保护植物 58种。主要包括以下几个类型：(1)野外种群数量极 小、极度濒危、随时有灭绝危险; (2)生境要求独特、 生态幅狭窄; (3)潜在基因价值不清楚、其灭绝将引 起基因流失、生物多样性降低、社会经济价值损失 巨大且种群数量相对较小(中华人民共和国林业局, 2011)。

本研究中, 我们通过收集整理全部120个极小 种群野生植物的 $10 \mathrm{~km} \times 10 \mathrm{~km}$ 的网格分布数据库, 分析了中国极小种群野生植物的分布格局, 并进一 步评估了中国极小种群野生植物就地保护的现状。 试图回答以下两个问题: (1)中国极小种群野生植物 分布在哪些区域? (2)这些极小种群野生植物在中国 的保护情况如何?

\section{数据和方法}

\section{1 物种分布数据的收集和丰富度的计算}

中国极小种群物种名录来自国家林业局网站 (http://www.forestry.gov.cn/)。通过以下途径收集了 这些物种的县域分布数据: (1)国家林业局采集数据 (http://www.forestry.gov.cn/); (2)国家级、省级及地方 植物志，各自然保护区名录，野外实地调查专著和 文献的分布数据; (3) 中国数字植物标本馆 (www.cvh.ac.cn); (4) 中国生物多样性红色名录 (http://www.zhb.gov.cn/gkml/hbb/bgg/201309/t2013091 2_ 260061.htm)。物种名录的统一以Flora of China 为准。然而, 对于极小种群植物, 县域水平的分布 数据会高估其分布范围，因此我们把县域分布数据 转化成 $10 \mathrm{~km} \times 10 \mathrm{~km}$ 分辨率网格分布并且剔除在 分布县域不符合该物种生存的生境类型和海拔生 长范围的网格。这一分辨率被广泛应用在区域和国 家尺度关于物种分布模型以及保护评估的研究中 (Irannezhad et al, 2015; Zhang et al, 2015a)。具体做 法为: 先收集每种植物的分布海拔上下限和适合 生长的生境类型(Flora of China Editorial Committee, 2006)。然后把极小种群的县域分布图、中国植被 分布图(1:1,000,000) (中国科学院中国植被图编辑 委员会, 2007)和中国数字高程图层(DEM, $30 \mathrm{~m}$ 分 辨率, http://reverb.echo.nasa. gov/reverb/redirect/wist/) 进行叠加，同时满足生境类型和分布海拔上下限的 网格中有该物种的分布，并据此在极小种群分布的 
县域中篮选出满足条件的网格, 从而实现把县域分 布数据转化成 $10 \mathrm{~km} \times 10 \mathrm{~km}$ 分辨率网格分布数据。 本研究一共收集了120个极小种群野生植物共计 7,434 条网格分布数据。

物种丰富度为每个网格拥有的物种数量的总和。

\section{2 中国自然保护区空间分布图}

截至2014年底, 我国建立了2,700多个自然保 护区，其中包括407个国家级和879个省级陆地自然 保护区。由于国家级和省级自然保护区覆盖了中国 所有陆地自然保护区面积的92\% (赵广华等, 2013), 而大多数地市级和县级自然保护区没有得到良好 的管理(权佳等, 2009), 并且这些地市级和县级保护 区的边界并不十分明确(赵广华等, 2013), 因此本研 究只探讨国家级和省级陆地自然保护区内植物的 保护现状。本研究中, 我们收集并数字化了其中359 个国家级和 835 个省级陆地自然保护区，制作了其 空间分布数据库。

\section{3 极小种群保护区保护现状评估分析}

本次评估的指标为极小种群植物的自然保护 区覆盖率。为了计算自然保护区对极小种群植物的 覆盖率, 我们将自然保护区图(国家级和省级)与物 种分布图叠加, 计算极小种群植物分布面积中受保 护区覆盖的比例，并确定极小种群植物的保护空白，
即分布范围中未被保护区覆盖的区域。

本研究所有统计分析都在 R软件 $(\mathrm{R}$ 2.15.1, R Development Core Team, 2013, http://www.r-project. org/)中进行, 数字化及叠加分析在ArcGIS 10.0软件 (ESRI, 2012)中完成。

\section{2 结果}

\section{1 极小种群野生植物丰富度的分布}

极小种群野生植物广泛分布于中国南方地区, 在云南的东南部、广西的西南部和海南岛的西南部 有较高的丰富度，均在 4 以上。丰富度最高的网格位 于海南省陵水、乐东黎族自治县, 均有 11 种。在四 川、重庆、湖南、江西、福建和吉林也有部分极小 种群野生植物的分布，丰富度在1左右，其他地方 几乎没有极小种群野生植物的分布(图1)。

\section{2 自然保护区对极小种群野生植物的保护现状} 评估

国家级自然保护区对极小种群野生植物分布 区的平均覆盖率为 $21.5 \%$, 有35种(占总数的 $29 \%$ )未 受任何国家级自然保护区覆盖。省级自然保护区对 极小种群野生植物分布区的平均覆盖率为 $10.9 \%$ 。 另外有 17 种极小种群野生植物(占总数的 $14 \%$ )未受 自然保护区覆盖(图2)。

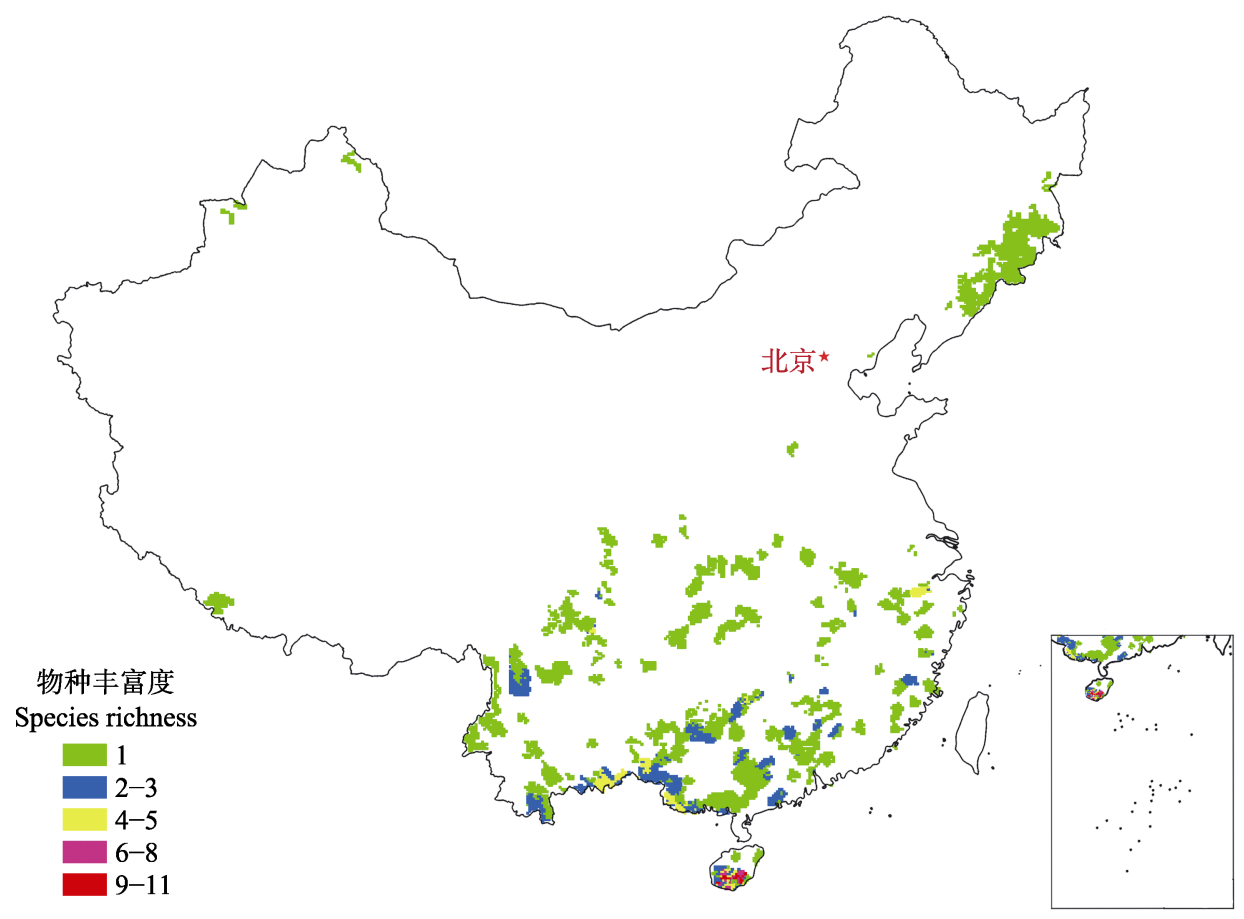

图1 中国极小种群野生植物丰富度分布格局

Fig. 1 Distribution of richness of Wild Plant Species with Extremely Small Populations (PSESP) 


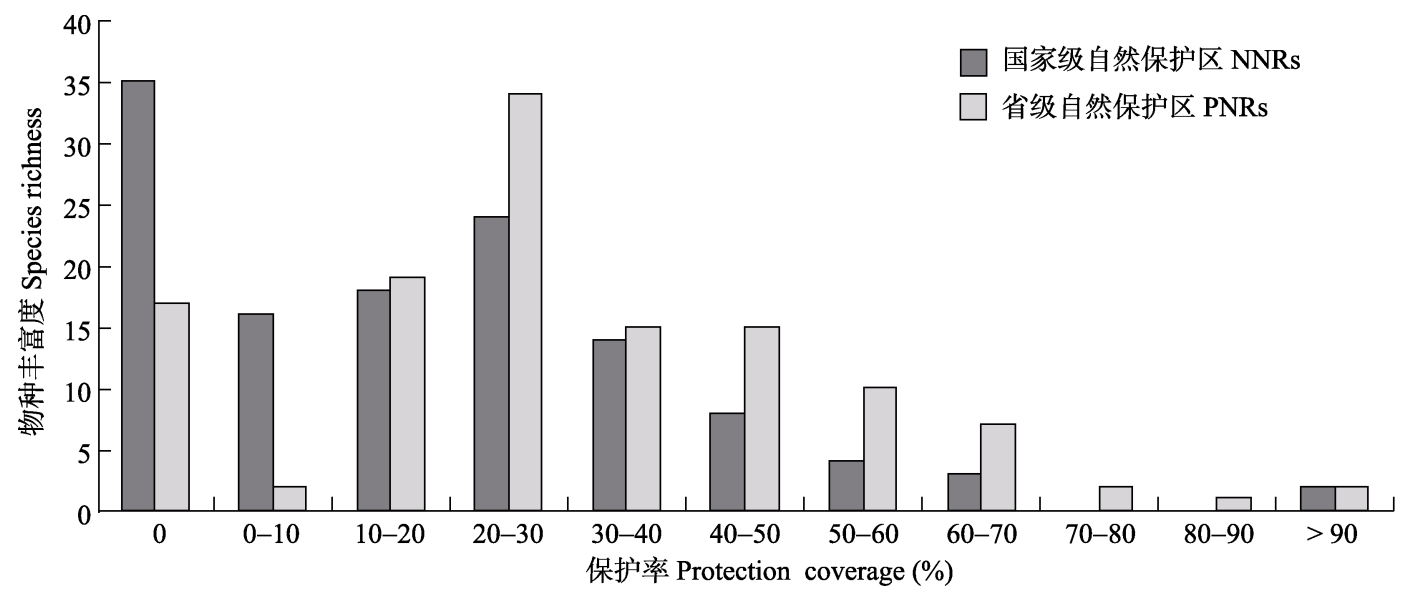

图2 中国极小种群野生植物分布区受国家级、省级自然保护区覆盖率的频率分布

Fig. 2 Frequency distribution of percentage of distribution area covered by national nature reserves (NNRs) and provincial nature reserves (PNRs) in China for Wild Plant Species with Extremely Small Populations (PSESP)

(a)

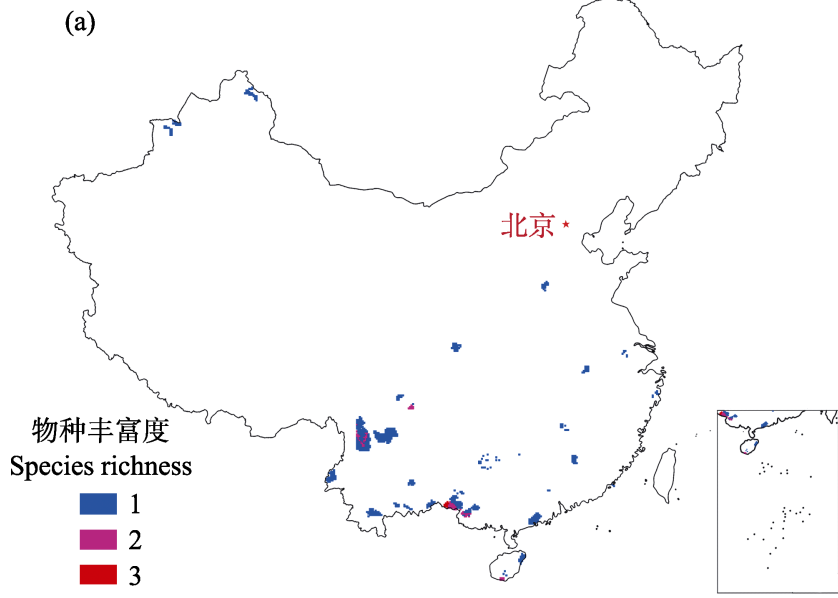

(b)

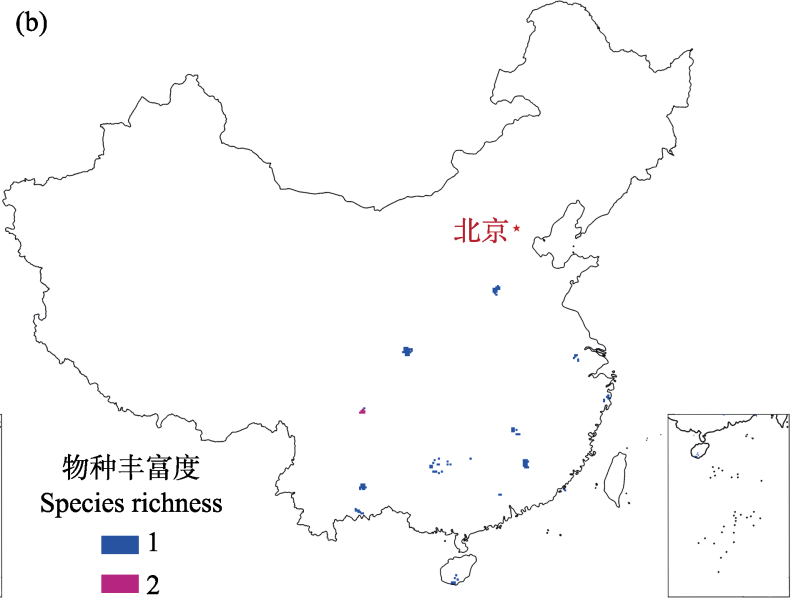

图3 中国未受国家级(a)以及国家级和省级自然保护区覆盖(b)的极小种群野生植物丰富度分布

Fig. 3 Distribution of richness of Wild Plant Species with Extremely Small Populations (PSESP) not covered by national nature reserves (a) and by either national or provincial nature reserves (b) in China

未受国家级自然保护区覆盖的极小种群野生 植物主要分布在我国的云南北部、广西西南部和海 南岛(图3a)。未受国家级和省级保护区覆盖的极小 种群野生植物则主要分布在我国四川中部、贵州西 部和海南岛西南部(图3b)。

\section{3 讨论}

相较于以往的研究, 本研究有两个特点: (1)我 们首次收集和制作了全国范围内较高空间分辨率 $(10 \mathrm{~km} \times 10 \mathrm{~km})$ 的物种分布研究极小种群野生植物 多样性分布格局; (2)结合国家级和省级自然保护区 分布图, 探讨了中国极小种群野生植物的保护现状, 并确定了保护优先区。然而, 由于本文数据主要来
自植物志、植物名录和野外实地调查专著和文献, 缺少实地调查, 可能在某种程度上会高估极小种群 野生植物分布区面积。

研究表明, 极小种群野生植物广泛分布于中国 南方地区, 在云南的东南部、广西的西南部和海南 岛的西南部有较高的丰富度。这一分布格局和中国 受威胁植物的分布格局比较相似, 极小种群野生植 物丰富度高的南方地区受威胁物种的丰富度也比 较高(Zhang et al, 2015b)。国家级自然保护区覆盖了 85 种(占总数的 $71 \%$ )极小种群植物, 省级自然保护 区新增覆盖了另外18种(15\%)的极小种群植物, 其 余未受保护区覆盖的极小种群野生植物主要分布 在我国的西南地区。 
由于极小种群野生植物分布范围小, 个体数量 少以及对外部环境如人类活动和气候变化敏感 (Myers et al, 2000; Huang, 2011), 它们比其他植物 更容易遭受灭绝，其生存面临诸多威胁。主要威胁 包括：(1)人类对野生植物的需求导致人为的采集和 采伐。大部分极小种群野生植物具有经济、药用和 观赏价值, 可提供优质木材、药材, 被当地群众非 可持续性采挖, 逐步走向灭绝(潘红丽, 2014); (2)全 球气候变化等因素导致生境丧失, 加上人类对资源 的不正当开发，例如采矿、开荒等，导致生境碎片 化(Yang \& Yang, 2014); (3)自身因素导致物种衰退, 环境压力及自身的种子生理特性导致物种遗传多 样性、生殖力、生活力和适应力等方面的衰退, 物 种种群大小不断减小。例如, 线毛皇荚(Gleditsia japonica var. velutina), 原有原生种4株, 有2株分布 在南岳，随时有灭绝的危险(廖菊阳等, 2015)。

研究极小种群植物分布的重要意义已经在其 他研究中得到证实, 关注极小种群植物的保护可以 更好地保护其他物种(Warman et al, 2004)。全球或 区域研究表明，虽然目前全球的保护区网络体系日 趋完善，考虑到人类活动和土地利用加剧，目前的 保护区网络体系并不能很好地满足对受威胁植物 的保护(Wilson et al, 2005; Pauchard et al, 2006; Schipper et al, 2008; Tognelli et al, 2008)。本研究中 所用国家级和省级自然保护区大约覆盖了 $13.7 \%$ 的 国土面积, 保护的中国极小种群植物数量仅相当于 全国 3\%的受威胁植物数量(Zhang et al, 2015b)。对 极小种群的保护工作需要从两个方面加强: (1)加强 就地保护工作。云南和海南岛具有最多未受保护区 覆盖的极小种群野生植物以及包括兰科植物在内 的受威胁植物(Zhang et al, 2015a, b), 因此亟待在当 地建立新的自然保护区或优先升级现有的保护极 小种群野生植物的省级保护区，同时加强保护区管 理以提高现有保护区的有效性(Armesto, 1998; 赵 广华等, 2013); (2)完善迁地保护工作。依托现有植 物园和种源繁育基地, 专门针对极小种群植物开展 迁地保护, 建议在海南、云南、湖南、四川等地, 特 别是重点县市如乐东、陵水等, 建立植物园迁地保 护体系, 并加强对极小种群植物保育的功能。对经 济效益、观赏价值和科研价值较高的极小种群物 种如观光木 (Michelia odora) 和大黄花虾脊兰 (Calanthe sieboldii)等, 需要依托科研单位进行规模
化繁育, 加快繁殖技术研究, 实现规模化种植和生 产, 逐步满足社会需求, 缓解濒危态势(廖菊阳等, 2015)。

\section{参考文献}

Armesto JJ (1998) Conservation targets in South American temperate forests. Science, 282, 1271-1272.

Balmford A, Green RE, Jenkins M (2003) Measuring the changing state of nature. Trends in Ecology \& Evolution, 18, 326-330.

Brugiere D, Scholte P (2013) Biodiversity gap analysis of the protected area system in poorly-documented Chad. Journal for Nature Conservation, 21, 286-293.

Editorial Committee of Vegetation Map of China (2007) Vegetation Map of the People's Republic of China $(1: 1000,000)$. Geological Publishing House, Beijing. (in Chinese) [中国科 学院中国植被图编辑委员会 (2007) 中国植被图集 $(1: 1000,000)$. 地质出版社, 北京.]

ESRI (2012) ArcGIS Desktop: Release 10.0. Environmental Systems Research Institute, Redlands, CA.

Flora of China Editorial Committee (2006) Flora of China. Science Press, Beijing and Missouri Botanical Garden Press, St. Louis, Missouri.

Grenyer R, Orme CDL, Jackson SF, Thomas GH, Davies RG, Davies TJ, Jones KE, Olson VA, Ridgely RS, Rasmussen PC, Ding TS, Bennett PM, Blackburn TM, Gaston KJ, Gittleman JL, Owens IPF (2006) Global distribution and conservation of rare and threatened vertebrates. Nature, 444, 93-96.

Huang H (2011) Plant diversity and conservation in China: Planning a strategic bioresource for a sustainable future. Botanical Journal of the Linnean Society, 166, 282-300.

Irannezhad M, Chen D, Klove B (2015) Interannual variations and trends in surface air temperature in Finland in relation to atmospheric circulation patterns, 1961-2011. International Journal of Climatology, 35, 3078-3092.

Kullberg P, Moilanen A (2014) How do recent spatial biodiversity analyses support the convention on biological diversity in the expansion of the global conservation area network? Natureza \& Conservacao, 12, 3-10.

Liao JY, Peng CL, Tian XM (2015) Study on the current situation and protection countermeasures of PSESP plant resources in Hunan. Chinese Botanical Garden, (18), 47-54. (in Chinese) [廖菊阳, 彭春良, 田晓明 (2015) 湖南极小 种群野生植物资源及保护对策研究. 中国植物园, (18), 47-54.]

Millennium Ecosystem Assessment (2005) Ecosystems and human well-being: Synthesis. Ecological Management \& Restoration, 3, 226-227.

Monastersky R (2014) Biodiversity: life-a status report. Nature, 516, 158-161.

Myers N, Mittermeier RA, Mittermeier CG, da Fonseca GAB, 
Kent J (2000) Biodiversity hotspots for conservation priorities. Nature, 403, 853-858.

Pan HL, Feng QH, Long TL, He F, Liu XL (2014) Discussion on resource condition and protection technique for rare endanged species in Sichuan Province. Journal of Sichuan Forestry Science and Technology, 35(6), 41-46. (in Chinese with English abstract) [潘红丽, 冯秋红, 隆廷伦, 何飞, 刘 兴良 (2014) 四川省极小种群野生植物资源现状及其保 护研究. 四川林业科技, 35(6), 41-46.]

Pauchard A, Aguayo M, Peña E, Urrutia R (2006) Multiple effects of urbanization on the biodiversity of developing countries: The case of a fast-growing metropolitan area (Concepción, Chile). Biological Conservation, 127, 272-281.

Quan J, Ouyang ZY, Xu WH, Miao H (2009) Management effectiveness of China nature reserves: Status quo assessment and countermeasures. Chinese Journal of Applied Ecology, 20, 1739-1746. (in Chinese with English abstract) [权佳, 欧阳志云, 徐卫华, 苗鸿 (2009) 中国自然保护区 管理有效性的现状评价与对策. 应用生态学报, 20, 1739-1746.]

Rabb GB, Sullivan TA (1995) Coordinating conservation-global networking for species survival. Biodiversity and Conservation, 4, 536-543.

Rands MR, Adams WM, Bennun L, Butchart SH, Clements A, Coomes D, Entwistle A, Hodge I, Kapos V, Scharlemann JP (2010) Biodiversity conservation: Challenges beyond 2010. Science, 329, 1298-1303.

Ren H, Zhang QM, Lu HF, Liu HX, Guo QF, Wang J, Jian SG, Bao HO (2012) Wild plant species with extremely small populations require conservation and reintroduction in China. AMBIO, 41, 913-917.

Rodrigues AS, Andelman SJ, Bakarr MI, Boitani L, Brooks TM, Cowling RM, Fishpool LD, da Fonseca GA, Gaston KJ, Hoffmann M, Long JS (2004) Effectiveness of the global protected area network in representing species diversity. Nature, 428, 640-643.

Schipper J, Chanson JS, Chiozza F, Cox NA, Hoffmann M, Katariya V, Lamoreux J, Rodrigues AL, Stuart S, Temple HJ (2008) The status of the world's land and marine mammals: Diversity, threat, and knowledge. Science, 322, 225-230.

State Forestry Administration of P. R. China (2011) General Planning of National Wildlife and Nature Reserve Construction Project. (in Chinese) [中华人民共和国林业局 (2011) 全国野生动植物保护及其自然保护区建设工程总体规划] http://www.forestry.gov.cn/ (accessed on 2014-05-06)
Tang XP (2012) Classification management pattern of nature reserves and its effectiveness. Journal of Beijing Forestry University, 11(4), 44-48. (in Chinese with English abstract) [唐小平 (2012) 自然保护区分级管理模式及其有效性研 究. 北京林业大学学报, 11(4), 44-48.]

Teller BJ, Miller AD, Shea K (2015) Conservation of passively dispersed organisms in the context of habitat degradation and destruction. Journal of Applied Ecology, 52, 514-521.

Tognelli MF, de Arellano PIR, Marquet PA (2008) How well do the existing and proposed reserve networks represent vertebrate species in Chile? Diversity and Distribution, 14, 148-158.

Warman LD, Forsyth DM, Sinclair ARE, Freemark K, Moore HD, Barrett TW, Pressey RL, White D (2004) Species distributions, surrogacy, and important conservation regions in Canada. Ecology Letters, 7, 374-379.

Wilson K, Newton A, Echeverría C, Weston C, Burgman M (2005) A vulnerability analysis of the temperate forests of south central Chile. Biological Conservation, 122, 9-21.

Wu TY, Walther BA, Chen YH, Lin RS, Lee PF (2013) Hotspot analysis of Taiwanese breeding birds to determine gaps in the protected area network. Zoological Studies, 52, 29.

Yang WZ, Yang YM (2014) Conservation priorities of Wild Plant Species with Extremely Small Populations (PSESP) in Yunnan Province. Journal of West China Forestry Science, 43, 1-9.

Zhang ZJ, He J-S, Li JS, Tang ZY (2015a) Distribution and conservation of threatened plants in China. Biological Conservation, 192, 454-460.

Zhang ZJ, Yan YJ, Tian Y, Li JS, He J-S, Tang ZY (2015b) Distribution and conservation of orchid species richness in China. Biological Conservation, 181, 64-72.

Zhao GH, Tian Y, Tang ZY, Li JS, Zeng H (2013) Distribution of terrestrial national nature reserves in relation to human activities and natural environments in China. Biodiversity Science, 21, 658-665. (in Chinese with English abstract) [赵 广华, 田瑜, 唐志尧, 李俊生, 曾辉 (2013) 中国国家级 陆地自然保护区分布及其与人类活动和自然环境的关系. 生物多样性, 21, 658-665.]

Zhou Y, Jiang H, Yang WZ, Zhang SS, Xiang ZY (2012) Study on stock of Pinus wangii, an extremely small population species. Journal of West China Forestry Science, 41, 80-83. (in Chinese with English abstract) [周云, 蒋宏, 杨文忠, 张珊珊, 向振勇 (2012) 极小种群植物毛枝五针松的野 生资源状况研究. 西部林业科学, 41, 80-83.]

(责任编委：臓润国 责任编辑：问文杰) 